\title{
KEPADATAN MAKROZOOBENTOS DI DAERAH BERVEGETASI (LAMUN) DAN TIDAK BERVEGETASI DI TELUK DORERI MANOKWARI
}

\author{
Macrozoobenthos Abundance in the Vegetated (Seagrass) \\ and Un-vegetated Areas of Doreri Bay-Manokwari \\ Simon P.O Leatemia ${ }^{1 *}$, Enriani L. Pakilaran ${ }^{1}$ dan Herry Kopalit ${ }^{1}$ \\ ${ }^{1}$ Jurusan Perikanan, FPIK UNIPA, Manokwari, 98314, Indonesia \\ *Korespondensi: simonleatemia@yahoo.com
}

\begin{abstract}
ABSTRAK
Daerah bervegetasi lamun merupakan habitat berbagai jenis hewan, termasuk hewan bentos yang berperan penting dalam rantai makanan pada ekosistem lamun. Penelitian ini bertujuan untuk mengetahui komposisi, kepadatan, keanekaragaman dan dominansi spesies makrozoobentos pada daerah bervegetasi lamun dan tidak bervegetasi. Pengambilan sampel dilakukan pada 4 stasiun di Teluk Doreri, dengan alat corer yang berdiameter 3 inchi, dan dibenamkan sedalam $20 \mathrm{~cm}$ dari permukaan substrat. Hasil penelitian menunjukkan komposisi spesies makrozoobentos di daerah bervegetasi (lamun) lebih tinggi (125 spesies) dibandingkan daerah yang tidak bervegetasi (58 spesies), yang didominasi oleh gastropoda. Demikian pula dengan kepadatan spesies yang lebih tinggi pada daerah bervegetasi lamun (0,070-0,085 ind/2738,06 $\left.\mathrm{cm}^{3}\right)$, dibandingkan dengan daerah yang tidak bervegetasi $\left(0,035-0,067\right.$ ind/2738,06 $\left.\mathrm{cm}^{3}\right)$ pada semua stasiun. Hasil uji t juga menunjukkan ada perbedaan yang nyata antara kepadatan makrozoobentos yang ditemukan di daerah bervegetasi dan daerah tidak bervegetasi.
\end{abstract}

Kata kunci: makrozoobenthos, lamun, Teluk Doreri

\begin{abstract}
Area of seagrasses vegetation are the habitat of various types of animals, including benthic animals were they play an important role in the food chain of the seagrass ecosystem. This study aimed to determine the composition, abundance, diversity and dominance of macrozoobenthic species in vegetated and non-vegetated seagrassses. Sampling was conducted on 4 stations in Doreri Bay, with a 3 inch diameter of corer, and immersed as deep as $20 \mathrm{~cm}$ from the surface of the substrate. The results showed that the composition of macrozoobenthic species in the vegetated areas (seagrasses) was higher (125 species) than non-vegetated (58 species), was dominated by the gastropod. Similarly, higher density of the species in the seagrassed vegetation area $(0.070-0.085$ ind / $2738.06 \mathrm{~cm} 3)$, compared with non-vegetated $(0.035-0.067$ ind $/ 2738,06 \mathrm{~cm} 3)$ regions in all stations. The t test results also mean there is a marked difference between the density of macrozoobenthos found in vegetated and non-vegetated regions.
\end{abstract}

Key words: Macrozoobenthos, seagrass, Doreri Bay 


\section{PENDAHULUAN}

Pengkajian kualitas perairan dapat dila-kukan dengan berbagai cara, seperti dengan analisis fisika dan kimia air, serta analisis biologi. Perairan yang dinamis, analisis fisika dan kimia air kurang memberikan gambaran sesungguhnya mengenai kualitas perairan dan dapat menyebabkan penyimpangan yang kurang menguntungkan, karena kisaran nilainilai perubahannya sangat dipengaruhi oleh keadaan sesaat. Butler (1978) menyatakan bahwa dalam lingkungan yang dinamis, analisis biologi khususnya analisis struktur komunitas hewan bentos (komposisi, kepadatan, keanekaragaman, keseragaman, dan dominansi), dapat memberikan gambaran yang jelas tentang kuali-tas perairan.

Organisme bentos adalah organisme yang hidup di dasar, baik yang hidup di permukaan maupun di bawah permukaan yang menempel, merayap dan yang bergerak di dasar perairan. Bentos memiliki peranan yang sangat penting yaitu sebagai mata rantai penghubung dan aliran energi, sebagai penyedia makanan bagi tingkat trofik yang lebih tinggi, dan bentos merupakan salah satu parameter biologi yang dapat digunakan untuk mengetahui kualitas perairan karena hidupnya relatif menetap, tidak bermigrasi walaupunada perubahan kondisi lingkungan, mudah diambil, sensitif terhadap polusi organik. Ekosistem lamun merupakan salah satu ekosistem penunjang kehidupan di wilayah pesisir dan laut yang memiliki kemampuan sebagai penyaring dan pengikat se-dimen dan nutrien, serta memberi oksigen ba-gi organisme laut, selain itu juga berfungsi sebagai tempat bertelur dan mencari makan bagi organisme laut, di antaranya adalah hewan bentos.

Banyak penelitan yang menjelaskan dam-pak tumbuhan makrofita terhadap kumpulan epifauna (Mouillot et al., 2005 a, b). Beberapa pe-nelitian lainnya juga telah menjelaskan kelimpahan dan keanekaraga-man makrozoo-bentos pada daerah bervegetasi lamun dan tidak bervegetasi (Bergey et al., 1992; Connolly, 1997; Mistri et al., 2000; Hedgel \& Kriwoken, 2001), mereka mene- mukan bahwa kekayaan dan kepadatan spesies lebih tinggi di daerah bervegetasi dibanding daerah yang tidak bervegetasi. Sebaliknya Levin et al., 1998 menemukan kelimpahan makrozoobenthos yang lebih tinggi pada daerah bervegetasi (Spartina marsh), namun kekayaan spesies lebih tinggi pada daerah tidak bervegetasi dengan substrat berlumpur. Selain itu Lana \& Guiss (1992) menemukan hubungan yang negative antara bio-massa tumbuhan dengan jumlah epifauna di pantai Selatan Brazil.

Perairan Manokwari khususnya daerah pe-sisir yaitu Pantai Rendani, Pulau Mansinam, Pulau Lemon, Pantai Briosi BLK (Balai Latihan Kerja), Pantai Padarni dan perairan Pantai Wosi, khususnya karena Pantai Wosi merupakan perairan pesisir dengan ekosistem lamun yang cukup luas namun sangat berpotensi tercemar limbah antropoganik. Seiring dengan dijadikannya Manokwari sebagai Ibu Kota Provinsi Papua Barat, aktivitas pembangunan yang diarahkan ke wilayah pesisir tidak dapat dihindari. Dampak pembangunan ini berpeluang menyebabkan terjadinya pencemaran lingkungan yang pada akhirnya merusak ekosistem serta organisme di pesisir dan laut yang membuat keseimbangan lingkungan terganggu. Melihat kondisi ini perlu dila-kukan penelitian untuk mengetahui apakah kepadatan makrozoobentos di daerah bervegetasi (lamun) lebih tinggi dibandingkan dengan daerah yang tidak bervegetasi yang ada di Teluk Doreri.

Penelitian ini bertujuan untuk mengetahui komposisi, kepadatan, keanekaragaman, keseragaman dan dominansi makrozoobentos di daerah bervegetasi lamun dan tidak bervegetasi.

\section{METODE PENELITIAN}

Pengambilan contoh makrozoobentos di-lakukan di perairan pesisir Teluk Doreri, yaitu di pesisir Pulau Lemon (Stasiun I), Padarni (Stasiun II), Wosi (Stasiun III) dan Rendani (Stasiun IV) yang dapat dilihat pada Gambar 1. Pengambilan data dilakukan pada bulan Maret sampai Juli 2013. Jumlah titik pengambilan contoh dilakukan sebanyak 8 titik pada daerah 
bervegetasi (lamun) dan 8 titik pada daerah tidak bervegetasi pada tiap stasiun. Setiap lamun yang ditemukan pada titik pengambilan contoh pada setiap stasiun, diidentifikasi dengan mengacu pada buku identifikasi menurut Lanyon (1968), McKenzie et al. (2003) dan Susetiono (2004).

Pengambilan contoh makrozoobentos dilakukan saat kondisi air surut di daerah bervegetasi (lamun) dan tidak bervegetasi dengan menggunakan corer yang berdiameter 3 inch. Substrat dasar diambil sedalam $20 \mathrm{~cm}$, pada daerah bervegetasi dan tidak bervegetasi. Pada masing-masing daerah diambil sebanyak 4 titik pengambilan sampel secara acak. Substrat yang diperoleh diletakkan di atas ayakan dengan mesh size $0,5 \mathrm{~mm}$, kemudian diayak untuk memisahkan organisme dari substrat dan serasah. Contoh substrat yang tertinggal diayakan di-masukkan ke dalam plastik sampel dan diberi pengawet formalin $4 \%$ yang telah dicampur rose bengal. Setelah itu, subs-trat di-sortir di atas baki untuk memisahkan orga-nisme dari substrat dan serasah lamun. Makrozoobentos yang diperoleh dimasukkan ke dalam botol sampel dan dibawa ke laboratorium untuk diidentifikasi. Makrozoobentos yang berukuran kecil diidentifikasi dengan bantuan mikroskop binokuler, sedangkan yang berukuran agak besar dan jelas terlihat diidentifikasi dengan bantuan kaca pembesar.

Identifikasi makrozoobentos dilakukan berdasarkan buku petunjuk Dharma (1988, 1992, 2005); Day (1962). Selain itu juga diambil sampel substrat tepat di samping titik pengambilan contoh makrozoobentos. Contoh substrat selanjutnya dibilas dengan air tawar untuk menghilangkan kadar garam sehingga tidak mempengaruhi hasil analisis. Contoh substrat kemudian dikeringkan di bawah sinar matahari selama 4-5 hari (matahari dalam kondisi bersinar penuh atau terik) hingga beratnya konstan. Setelah kering, contoh subs-trat diambil sebanyak 100 gr, kemudian disaring pada ayakan bertingkat. Hasil ayakan yang tertinggal di tiap saringan dengan ukuran mata ayakan berbeda, selanjutnya ditimbang. Data be-rat (gr) yang diperoleh, kemudian dihitung persen komulatif substrat berdasarkan Tabel skala Wentworth/Udden, yang dikelompokkan berdasarkan persentase liat (ukuran ayakan <0,038 $\mu \mathrm{m}$ ), debu (ukuran ayakan $0,063-0,038 \mu \mathrm{m})$ dan pasir (ukuran ayakan 2-0,063 $\mu \mathrm{m}$ ) (Bale \& Kenny , 2005). Penentuan tipe substrat dilakukan berdasarkan kamposisi persentase substrat yang dominan dari hasil analisis.

Dalam penelitian ini dilakukan pula pengukuran beberapa parameter fisikakimia air, seperti suhu, salinitas, $\mathrm{pH}$, dan oksigen terlarut (dissolved oxygen) yang dilakukan secara in situ. Kepadatan spesies makrozoobentos pada tiap stasiun diketahui berdasarkan rumus kepadatan (Odum, 1993)

$$
K=\frac{n i}{A}
$$

Keterangan: $\mathrm{K}=$ kepadatan $\left(\mathrm{ind} / \mathrm{cm}^{3}\right)$, ni $=$ jumlah spesies ke-i, $\mathrm{A}=$ luas area penga-matan $\left(\mathrm{cm}^{3}\right)$.

Nilai kepadatan spesies makrozoobentos ini selanjutnya diuji lanjut untuk menentukan apakah ada perbedaan yang nyata antara kepadatan spesies makrozoobentos pada daerah bervegetasi lamun dan tidak bervegetasi, meng-gunakan uji t. Keanekaragaman makrozoobentos diketahui berdasarkan Indeks keanekaragaman Shannon-Wienner (Krebs, 1989), keseragman spesies berdasarkan indeks keseragaman (Brower \& Zar, 1990), dominansi spesies berdasarkan indeks dominansi Simpson (Odum, 1993), dan Indeks Kesamaan Komunitas berdasarkan Indeks Sorenson (Wolda, 1981).

Keterangan:

$$
I S=\frac{2 c}{a+b} \times 100 \%
$$

IS = indeks Sorenson (\%), a = jumlah spesies di lokasi a, $b=$ jumlah spesies di lokasi $b, c=$ jumlah spesies di lokasi a dan b. Apabila nilai IS $>75 \%$ berarti spesies makrozoo-bentos pada kedua lokasi sama, dan seba-liknya jika $<75 \%$ maka spesies makrozoobentos pada kedua lokasi tidak sama. 


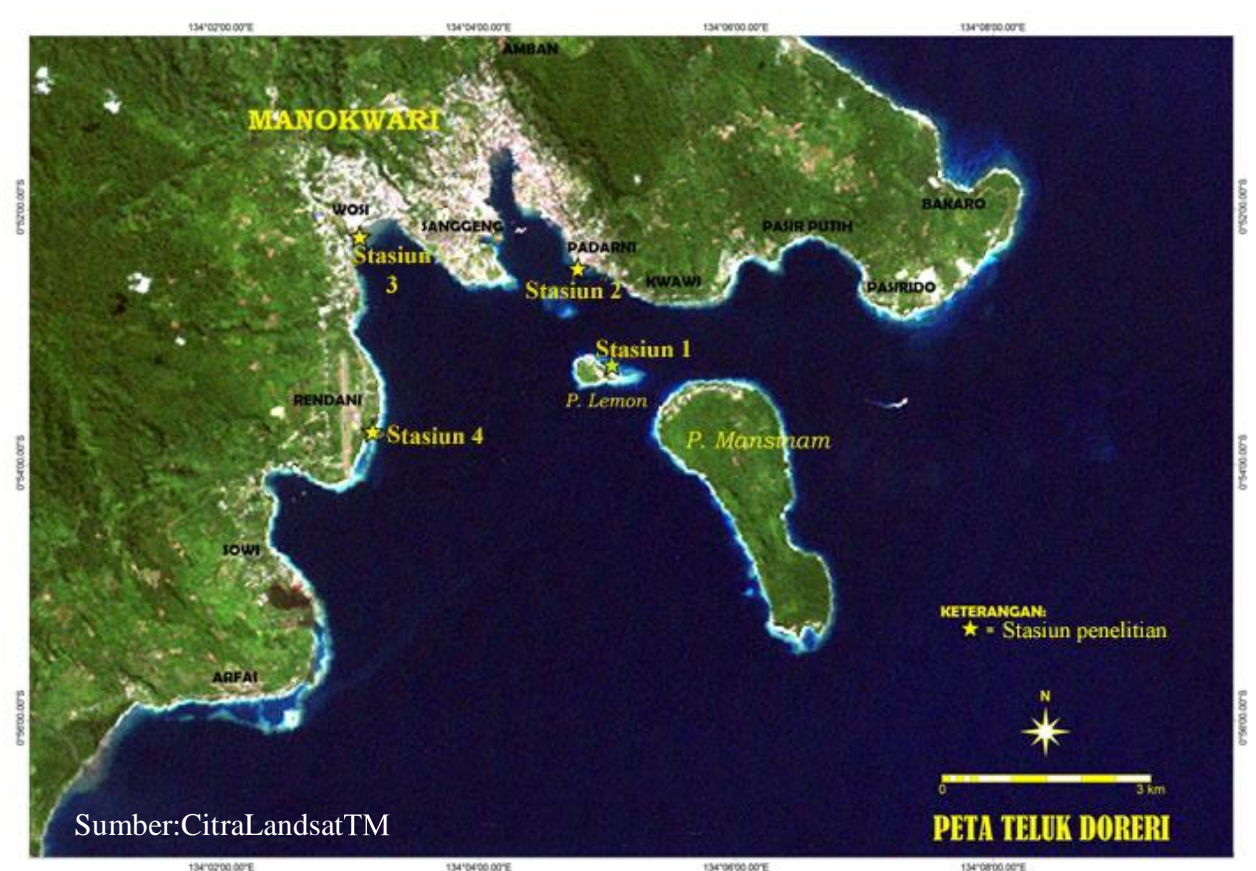

Gambar 1. Stasiun pengambilan data di Teluk Doreri, Manokwari

\section{HASIL DAN PEMBAHASAN}

\section{Tipe substrat dan kualitas air}

Stasiun I di Pulau Lemon memiliki struktur dasar pantai ke arah lereng secara berurutan adalah pasir, pasir bercampur karang mati, hamparan lamun, terumbu karang yang landai, hingga lereng terumbu karang. Stasiun II di Padarni memiliki tipe substrat ke arah laut secara berurutan adalah pasir, lumpur ber-pasir, pasir berbatu dan patahan karang mati, hamparan lamun, lereng terumbu karang. Kondisi perairan di stasiun II tidak terlalu jernih dibandingkan stasiun I. Stasiun III di Wosi memiliki karakter dasar perairan pantai yang landai, yang didominasi oleh pasir dan cukup luas. Stasiun Wosi terletak di dalam Teluk kecil, sehingga relatif terlindungi. Tipe sedimen di stasiun III adalah terrigenous dan kondisi perairannya lebih keruh karena merupakan daerah muara Sungai Wosi. Stasiu IV di Rendani merupakan daerah rataan terumbu karang yang landai dan cukup luas, juga ter-dapat ekosistem mangrove yang tidak luas pada bagian tepi pantai. Substrat perairan di stasiun IV sebagian besar tersusun dari sedi-men carbonat yang terdiri dari pasir dan pecahan karang. Hasil pengukuran suhu di empat stasiun pada daerah bervegetasi lamun dan tidak bervegetasi, berkisar antara 29$30^{\circ} \mathrm{C}$. Suhu terendah terdapat pada stasiun II yaitu $29^{\circ} \mathrm{C}$. Kisaran nilai tersebut masih berada pada kisaran toleransi hewan makrozoobentos. Menurut Sukarno (1988), suhu dapat membatasi sebaran hewan makrozoobentos secara geografis dan suhu yang baik untuk pertumbuhan he-wan bentos berkisar antara $25-36^{\circ} \mathrm{C}$.

Pada semua stasiun di daerah bervegetasi, ditemukan kisaran oksigen terlarut (DO) antara 2,13-9 mg/l. Kisaran DO terendah ditemukan stasiun II, dan stasiun dengan kan-dungan DO yang paling tinggi di stasiun III. Konsentrasi DO yang rendah sangat berkaitan dengan waktu pengukuran yang dilakukan saat surut te-rendah di hamparan lamun. Kondisi yang sama juga dinyatakan oleh Pescod (1973), bahwa kan-dungan oksigen terlarut minimal $2 \mathrm{mg} / \mathrm{l}$ untuk dapat mendukung kehidupan organisme secara normal di perairan tropis. Oksigen terlarut yang terukur pada semua stasiun penelitian di daerah 
yang tidak bervegetasi berkisar antara 2,20-7,83 mg/l. Kisaran DO terendah ditemukan di stasiun III dan yang tertinggi di stasiun I. Kandungan oksigen terlarut ini cenderung lebih rendah bila dibandingkan dengan daerah bervegetasi pada tiap stasiun. Hal ini disebabkan karena oksigen terlarut dalam perairan berasal dari proses fotosintesis oleh tumbuhan (lamun, alga maupun fitoplankton), dan difusi dari udara (APHA, 1989).

Salinitas pada daerah bervegetasi dan ti-dak bervegetasi berkisar antara 27$35 \%$. Salinitas terendah terdapat di stasiun II dan III. Kondisi ini terkait dengan masukan air tawar yang berasal dari daerah sekitarnya, seperti aliran sungai kecil dari permukiman penduduk di $\mathrm{Pa}-$ darni maupun sungai yang bermuara di dekat pasar Wosi. Salinitas di stasiun I dan IV yang terukur yaitu 30-35\%, lebih tinggi dibandingkan stasiun lainnya. Kelompok makrozoobentos yakni Gastropoda, Bivalvia, dan Krustacea yang ditemukan di stasiun I dan IV termasuk spesies yang toleran terhadap kisaran salinitas yang sempit (steno-haline). Salinitas yang terukur di Stasiun II dan III berkisar antara 27-28 \%o. Spesies makrozoobentos dari kelompo Gastropoda, Bivalvia, dan Polikaeta yang ditemukan di stasiun II dan III merupakan spesies yang tolerir terhadap kisaran salinitas yang lebar (euryhaline) (Nybakken, 1992). Nilai pH menunjukkan derajat keasaman/ kebasaan suatu perairan. Nilai $\mathrm{pH}$ di semua stasiun pada daerah bervegetasi, $\mathrm{pH}$ substrat adalah 6-7,4 dan $\mathrm{pH}$ air 7-8,04. Nilai $\mathrm{pH}$ substrat dan air yang terukur tergolong normal (APHA,1989), masih berada dalam kisaran toleransi makrozoobentos. Pennak (1978) mengatakan bahwa nilai $\mathrm{pH}$ yang mendukung kehidupan Moluska berkisar antara 5,78,4 . Hal ini dibuktikan dengan komposisi spesies yang relatif sama pada stasiun dengan $\mathrm{pH}$ rendah maupun yang paling tinggi berdasarkan hasil pengukuran. Nilai $\mathrm{pH}$ substrat yang diperoleh pada daerah tidak bervegetasi berkisar antara 6-7. Makrozoobentos yang ditemukan didominasi oleh kelas Gastropoda dan Bivalvia. Meskipun nilai $\mathrm{pH}$ subtrat di empat stasiun di daerah tidak bervegetasi berada pada kisaran toleransi makrozoobentos, namun pH air yang diperoleh menunjukan kisaran antara 2,80-8,29. Kisaran $\mathrm{pH}$ air terendah ditemukan di Stasiun II, ini terlihat dari komposisi makrozoobentos yang ditemukan paling sedikit dibandingkan stasiun lainnya. Kisaran $\mathrm{pH}$ yang lebar mempenga-ruhi kehidupan makrozoobentos di kedua sta-siun tersebut. Hasil ini diperkuat oleh pernya-taan Hynes (1978) menyatakan bahwa nilai $\mathrm{pH} \pm<5$ dan $>9$ menciptakan kondisi yang tidak mengguntungkan bagi kebanyakan organisme makrozoobentos.

Pada daerah bervegetasi di Stasiun I sam-pai IV memiliki tipe substrat yang didominasi oleh pasir berlempung. Ditinjau dari kebiasaan makannya, makrozoobentos yang banyak ditemukan adalah kelompok organisme pemakan deposit (deposit feeder), pemakan substrat dan karnivora (Barnes, 1987). Organisme yang ditemukan adalah Gastropoda, Bivalvia, dan krustasea. Kelompok organisme tersebut merupakan kelompok organisme yang cukup baik untuk beradaptasi terhadap dinamika kondisi substrat dasar perairan dalam mencari makanan.

Pada daerah yang tidak bervegetasi, tipe substrat di setiap stasiun berbeda-beda. Stasiun I didominasi oleh substrat lempung berpasir, stasiun II didominasi oleh substrat lempung berpasir dan pasir, stasiun III oleh substrat pasir berlempung, dan stasiun IV didominasi oleh substrat pasir dan lempung berpasir. Menurut Odum (1993), hewan bentos pe-makan deposit melimpah pada sedimen lempung dan lunak, dan organisme yang ter-masuk kelompok ini adalah Polikaeta dan Krustasea. Hewan bentos yang hidup pada butiran pasir atau lumpur adalah kelompok Moluska, Polikaeta dan Krus-tasea (Odum,1993). Kelas Polikaeta adalah kelompok yang memiliki permukaan tubuh yang lunak, yang ditemukan pada substrat pasir berlempung yang mana sedimen lempung merupakan daerah yang mengandung bahan organik tinggi (Nybakken, 1992). 


\section{Komposisi lamun}

Berdasarkan hasil penelitian menunjukkan bahwa terdapat satu spesies lamun yang sama pada empat stasiun penelitian, yaitu Halophila ovalis. Komposisi spesies lamun yang ditemukan di empat stasiun pengamatan dapat dilihat pada Tabel 1.

Tabel 1. Komposisi spesies lamun yang ditemukan pada stasiun penelitian

\begin{tabular}{|c|c|c|c|c|}
\hline \multirow{2}{*}{ Spesies Lamun } & \multicolumn{4}{|c|}{ Stasiun } \\
\hline & Pulau Lemon & Padarni & Wosi & Rndani \\
\hline Cymodocea rotundata & + & - & + & + \\
\hline Cymodocea serrulata & $-{ }_{-}^{*}$ & - *** & + & -** \\
\hline Halophila ovalis & + & + & + & + \\
\hline Halodule pinifolia & + & - -** & $-^{* * *}$ & - \\
\hline Halodule uninervis & - - & + & + & + \\
\hline Syringodium isoetifolium & - & + & - & $-^{* * *}$ \\
\hline Enhalus acoroides & - & - & $-^{* * *}$ & - \\
\hline
\end{tabular}

Keterangan :

+ : Ditemukan pada stasiun penelitian

- : Tidak ditemukan pada stasiun penelitian

*: Ditemukan oleh Kopalit (2010)

*** : Ditemukan oleh Leatemia (2010)

Hasil pengamatan menunjukkan bahwa lamun pada stasiun I dan IV tumbuh dengan baik karena kedua lokasi ini tidak banyak mengalami gangguan akibat aktivitas penduduk dan kondisi perairannya relatif jernih. Menurut Bengen (2002), lamun hidup di perairan yang dangkal dan jernih pada kedalaman 2-12 m, dengan sirkulasi air yang baik. Hal ini memungkinkan lamun dapat dijangkau oleh cahaya matahari sehingga dapat melakukan fotosintesis untuk menunjang pertumbuhannya.

\section{Komposisi dan kelimpahan makrozoo- bentos}

Makrozoobentos yang ditemukan di empat stasiun yang bervegetasi lamun terdiri atas 3 kelas yaitu Gastropoda (74,77 $\%)$, Bivalvia $(24,77 \%)$, dan Krustasea $(0,46 \%)$, yang terbagi dalam 41 famili, dan 113 spesies. Pada semua stasiun di daerah bervegetasi lamun, komposisi kelas makrozoobentos yang paling dominan adalah Gastropoda (Gambar 2a). Kondisi ini berkaitan dengan tipe substrat di daerah bervegetasi yang didominasi oleh substrat pasir sampai berlempung. Substrat yang ada di daerah bervegatasi banyak me-ngandung bahan organik yang bersumber dari luruhan daun-daun lamun yang membusuk dan terperangkap di sedi- men dasar perairan (Kennish, 1990). Gastropoda dan hewan bentos lainnya memanfaatkan bahan organik tersebut sebagai sumber makanannya, sehingga kelompok gastropoda sangat melim-pah di daerah bervegetasi lamun. Hal yang sama dite-mukan oleh Leatemia (2010), yang mene-mukan gastropoda dengan jumlah yang me-limpah pada 4 habitat lamun yang ada di Teluk Doreri.

Jumlah individu spesies gastropoda paling sedikit terdapat di stasiun III dibandingkan dengan stasiun lainnya (Gambar 2a). Hal ini disebabkan oleh kadar salinitas yang berfluktuasi sehingga hanya makrozoobentos tertentu yang dapat mentolerir kondisi demi-kian, yang dapat hidup dengan baik. Pada stasiun III, jumlah individu spesies Bivalvia lebih dominan yakni sebanyak 29 ind (50,88 \%). Jumlah individu spesies Bivalvia yang lebih dominan didukung oleh tipe substrat pasir berlempung, yang merupakan habitat yang cocok bagi bivalvia. 


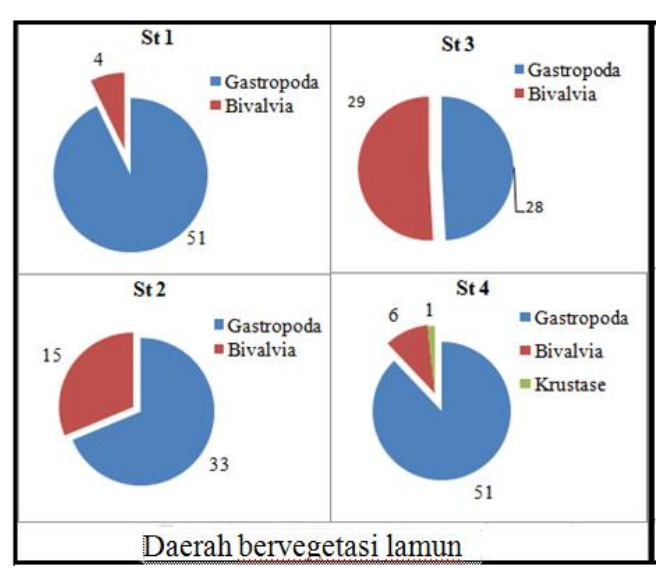

Gambar 2a. Komposisi makrozoobentos berdasarkan jumlah individu tiap spesies pada empat stasiun (St) di daerah bervegetasi lamun

Pada daerah tidak bervegetasi, makrozoobentos yang ditemukan pada empat stasiun termasuk dalam 3 kelas, yaitu Gastropoda (71,65\%), Bivalvia (26,77\%) dan Polikaeta (1,57 \%). Komposisi kelas paling dominan adalah Gastropoda dengan komposisi paling tinggi pada stasiun I dan IV (Gambar 2b). Komposisi spesies gastropoda yang tinggi berkaitan dengan tekstur substrat pada kedua stasiun yang didominasi oleh substrat pasir dan lempung berpasir. Menurut Odum (1993); Nybakken (1992), hewan bentos yang domi-nan hidup antara butiran pasir maupun lumpur, termasuk dalam kelompok Gastropoda, Polikaeta, Krustasea dan kelompok bakteri.

Pada Stasiun III, komposisi spesies Bi-valvia menunjukkan jumlah yang lebih banyak. Hal ini disebabkan karena tipe subs-trat di stasiun III didominasi oleh pasir dan lempung yang merupakan daerah yang disukai oleh Bivalvia. Pada Stasiun III juga ditemukan spesies dari kelas Polikaeta dengan jumlah paling sedikit yaitu 2 famili yaitu Glyceridae dan Capitellidae.

Kepadatan makrozoobentos di seluruh stasiun penelitian di daerah bervegetasi berkisar antara 0,070-0,084 ind $/ 2738,06 \mathrm{~cm}^{3}$. Nilai kepadatan terendah terdapat di Stasiun II (0,070 ind/ $2738,06 \mathrm{~cm}^{3}$ ) dan kepadatan tertinggi terdapat di Stasiun IV (0,084 ind/2738,06 $\mathrm{cm}^{3}$ ) (Gambar 3). Hasil yang sama dite- mukan juga oleh Leatemia dan Pat-tiasina (2008), dimana komposisi dan kelimpahan jenis makrozoobentos yang ditemukan di Rendani lebih tinggi dari tiga lokasi lainnya di Teluk Doreri, karena stasiun Rendani merupakan habitat yang lebih baik, terdapat hamparan lamun dan mangrove yang baik sebagai habitat bagi hewan bentos.

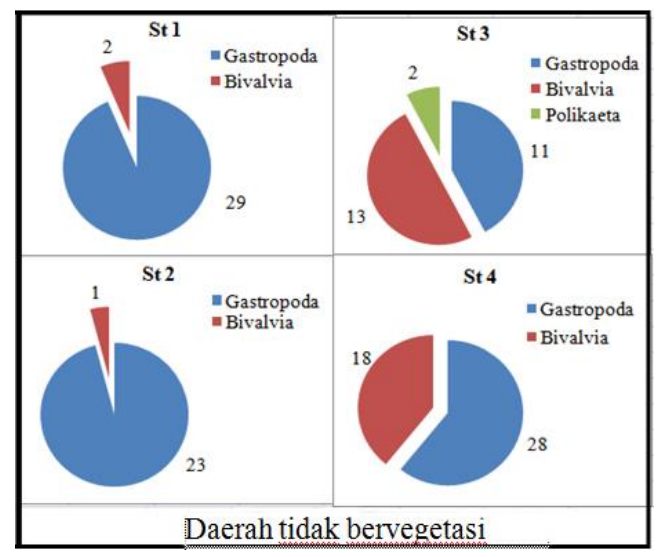

Gambar 2b. Komposisi makrozoobentos berdasarkan jumlah individu tiap spesies pada empat stasiun (St) pada daerah tidak bervegetasi

Kelas yang dominan di empat lokasi adalah Gastropoda yaitu 0,239 ind/ $2738,06 \mathrm{~cm}^{3}$ yang diikuti kepadatan Bivalvia 0,081 ind $/ 2738,06 \mathrm{~cm}^{3}$ dan Krustasea 0,001 ind/2738,06 $\mathrm{cm}^{3}$ (Tabel 2) Kepadatan Gastropoda paling tinggi di daerah bervegetasi amun ditemukan di stasiun I dan IV $(0,075$ ind $/ 2738,06$ $\mathrm{cm}^{3}$ ). Tingginya kepadatan gastropoda sangat berkaitan dengan tipe substrat pada kedua stasiun. Habitat lamun menyokong kelimpahan dan kekayaan hewan yang berasosiasi dengan memberikan struktur habitat secara fisik (Orth et al. 1984).

Hasil uji $t$ untuk membandingkan kepadatan antara makrozoobentos di daerah yang berbeda nyata antara kepadatan makrozoo-bentos di daerah bervegetasi dan tidak bervegetasi. Daerah bervegetasi lamun merupakan habitat yang baik dan merupakan tempat persinggahan fauna yang berasosiasi, karena: (1) vegetasi lamun sangat efektif meningkatkan area permukaan substrat bagi flora dan fauna epifit; (2) padang lamun mengurangi aksi 
arus dan ombak; (3) dapat mengurangi pergerakan air maka material tersuspensi dan partikel organik dapat lebih mudah me-ngendap di padang lamun yang dapat mening-katkan kesuburan permukaan padang lamun; (4) kanopi lamun memberikan bayangan pada dasar perairan, menyebabkan substrat lebih sedikit terkena cahaya matahari dibandingkan daerah sekitar yang tidak bervegetasi dan tidak bervegetasi menunjukkan terima $\mathrm{H} 1$, yang berarti ada perbedaan tertutupi.

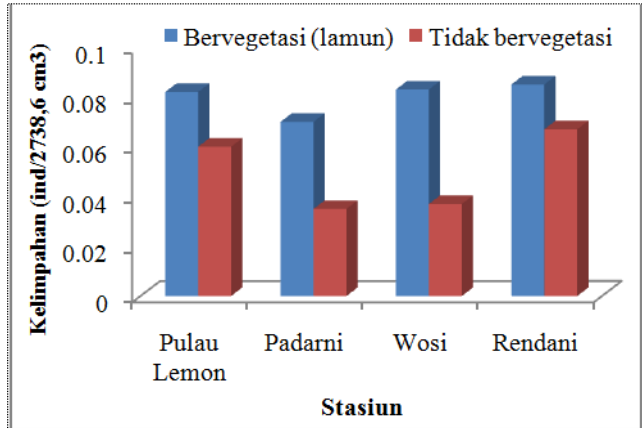

Gambar 3. Kepadatan makrozoobentos (ind./2738,06 $\mathrm{cm}^{3}$ ) pada empat stasiun di Teluk Doreri

Tabel 2. Kepadatan makrozoobentos daerah bervegetasi lamun dan tidak bervegetasi

\begin{tabular}{cccccccrr}
\hline \multirow{2}{*}{ Stasiun } & \multicolumn{3}{c}{ Daerah bervegetasi } & \multirow{2}{*}{ Total } & \multicolumn{3}{c}{ Daerah tidak bervegetasi } & \multirow{2}{*}{ Total } \\
& Gastropoda & Bivalvia & Krustasea & & Gastropoda & Bivalvia & Polikaeta & \\
\hline I & 0,075 & 0,007 & - & 0,081 & 0,056 & 0,004 & - & 0,045 \\
II & 0,048 & 0,022 & - & 0,052 & 0,034 & 0,001 & - & 0,026 \\
III & 0,041 & 0,042 & - & 0,063 & 0,016 & 0,019 & 0,003 & 0,028 \\
IV & 0,075 & 0,009 & 0,001 & 0,064 & 0,041 & 0,026 & - & 0,051 \\
Total & 0,239 & 0,08 & 0,001 & 0,320 & 0,147 & 0,05 & 0,003 & 0,200 \\
\hline
\end{tabular}

Keterangan:

- = tidak ditemukan

Kepadatan di daerah tidak bervegetasi berkisar antara 0,035-0,067 ind/ $2738,06 \mathrm{~cm}^{3}$. Kepadatan terendah terdapat di stasiun II yaitu 0,035 ind $/ 2738,06$ $\mathrm{cm}^{3}$ dan tertinggi di stasiun IV yaitu 0,067 ind/2738,06 $\mathrm{cm}^{3}$ (Gambar 3). Kelas yang dominan adalah Gastropoda yaitu 0,147 ind/2738,06 $\mathrm{cm}^{3}$ yang diikuti kepadatan Bivalvia 0,081 ind $/ 2738,06 \mathrm{~cm}^{3}$ dan Krustasea 0,003 ind/2738,06 $\mathrm{cm}^{3}$ (Tabel 2). Kelas Polikaeta merupakan kelompok makrozoobentos dengan kepadatan terendah, dan hanya dite-mukan pada stasiun III.

Kepadatan Bivalvia di Stasiun III lebih tinggi dari kepadatan Gastropoda, baik pada daerah bervegetasi lamun maupun tidak bervegetasi. Berdasarkan penelitian van Houte-Howes et al. (2004) menunjukkan hal yang sama, dimana hanya 2 spesies Bivalvia yang ditemukan pada lokasi yang tidak bervegetasi (Austrovenus stutchburyi dan Nucula hartvi-giana) dengan kepadatan yang tinggi. Bi-valvia dapat hidup dan tumbuh dengan baik pada tipe substrat berlumpur karena memiliki siphon yang panjang yang berguna untuk me-ngambil makanan dan tergolong pemakan deposit dan pemakan penyaring. Sedimen halus mengandung konsentrasi bahan organik yang tinggi sehingga dapat menyokong komunitas yang melimpah bagi makrozoobentos (Bivalvia) dengan tipe pemakan deposit dan pemakan penyaring (van Houte-Howes et al., 2004).

Terlindung dari cahaya matahari yang terang dan terjemur, serta batang lamun memberikan habitat dan keuntungan bagi organisme bentos; (5) kondisi perhentian dan suplai makanan yang melimpah menjadikan daya tarik padang lamun bagi hewan bentos (Kikuchi, 1980 dalam Kennish, 1990).

Indeks keanekaragaman, keseragaman dan dominansi merupakan indeksindeks ekologis yang sering digunakan untuk me-ngevaluasi kondisi lingkungan suatu perairan. Kondisi suatu perairan umumnya dapat dikatakan baik (stabil) bila memiliki indeks keanekaragaman dan keseragaman yang ting-gi serta dominansi yang rendah atau tidak ada spesies yang dominan (Odum, 1993). Hasil perhi- 
tungan indeks keaneka-ragaman di setiap stasiun penelitian pada daerah bevegetasi me-nunjukkan nilai terendah di Stasiun II yaitu 4,33 dan tertinggi di Stasiun IV yaitu 5,30. Pada daerah tidak bervegetasi nilai keaneka-ragaman terendah terdapat di stasiun I yaitu 3,31 dan tertinggi di stasiun IV yaitu 3,87. Menurut Brower dan Zar (1990), daerah yang bervegetasi memiliki kondisi lingkungan yang baik dan lebih stabil bagi kehidupan makrozoobentos dibandingkan dengan daerah tidak bervegetasi. Namun pada penelitian van Houte-Howes et al. (2004) menunjukkan tidak ada hubungan yang konsisten antara jumlah taksa dan keanekaragaman makrozoobentos yang ditemukan pada daerah bervegetasi dan tidak bervegetasi, namun korelasi antara kepadatan makrozoobentos berbanding lurus dengan biomassa dan kelimpahan lamun.

Tabel 3. Indeks keanekaragamanan (H'), keseragaman (E), dominansi (C) spesies makrozoobentos

\begin{tabular}{cllll}
\hline Indeks & St 1 & St II & St III & St IV \\
\hline \multicolumn{5}{c}{ Daerah bervegetasi lamun } \\
\hline H' & 4,76 & 4,33 & 4,92 & 5,30 \\
E & 0,93 & 0,93 & 0,95 & 0,97 \\
C & 0,05 & 0,06 & 0,04 & 0,18 \\
\hline \multicolumn{5}{c}{ Daerah tidak bervegetasi } \\
\hline H' & 3,31 & 3,68 & 3,51 & 3,87 \\
E & 0,83 & 0,90 & 0,92 & 0,87 \\
C & 0,18 & 0,12 & 0,11 & 0,11 \\
\hline
\end{tabular}

Keterangan:

$\mathrm{St}=$ stasiun

Indeks keseragaman menunjukkan nilai yang mendekati 1 pada daerah bervegetasi $(0,920-0,965)$ dan tidak bervegetasi $(0,827-0,921)$. Nilai indeks keseragaman terendah terdapat di stasiun I yaitu 0,929 dan nilai keseragaman tertinggi terdapat di stasiun III ya-itu 0,965 . Pada daerah tidak bervegetasi nilai indeks keseragaman terendah terdapat di stasiun I 0,827 dan indeks keseragaman tertinggi terdapat pada stasiun III 0,921. Nilai keseragaman yang tinggi pada daerah bervegetasi dan tidak bervegetasi pada stasiun III berkaitan dengan tingginya kandungan bahan orga-nik yang terkandung dalam sedimen baik pada daerah bervegetasi maupun tidak bervegetasi, yang berasal dari aliran sungai Wosi yang terendap di stasiun ini. Menurut van Houte-Howes et al. (2004) tidak ada variasi dalam karakteristik substrat antara daerah bervegetasi lamun dan tidak berve-getasi, sehingga kandungan bahan organik dalam substrat pada daerah bervegetasi dan tidak bervegetasi diduga sama.

Pada daerah bervegetasi indeks dominansi tertinggi terdapat di Stasiun Wosi yaitu 0,061. Spesies yang sangat dominan adalah Gari elongate, Vasticardium flavum (Bi-valvia) dan Mitrella puella (Gastropoda). Sedangkan pada daerah tidak bervegetasi, dominansi spesies tertinggi terdapat di Stasiun Pulau Lemon yaitu 0,178 . Spesies yang dominan adalah Vexillum caveum (Gastropoda), yang menyukai daerah berpasir. Berdasarkan indeks dominansi terlihat jelas bahwa Bivalvia lebih melimpah pada stasiun dengan tipe substrat pasir berlempung yang mengandung bahan organik dan sedimen yang tinggi seperti di Stasiun Wosi. Kisaran nilai ketiga indeks menunjukkan bahwa komunitas makrozoobentos pada lokasi penelitian di Teluk Doreri (Pulau Lemon, Padarni, Wosi, dan Rendani) masih berada dalam kondisi yang stabil. Kestabilan spesies dalam suatu komunitas terjadi jika nilai keanekaragaman dan keseragaman tinggi, dominansi spesies rendah (Laetemia, 2010).

Kesamaan komunitas berdasarkan kesa-maan spesies makrozoobentos pada empat stasiun, di daerah bervegetasi memiliki nilai indeks Sorenson (IS) berkisar antara 5,56-13,11 \%. Nilai ini menunjukan bahwa spesies makrozoobentos yang ditemukan pada tiap stasiun yang bervegetasi lamun berbeda atau tidak sama, karena nilai IS kurang dari 75 $\%$ (Wolda, 1981). Demikian pula nilai IS pada daerah tidak bervegetasi di tiap stasiun menunjukkan nilai $<75 \%$, di-mana nilai IS yang diperoleh berkisar antara 6,25-20\%. Nilai ini menunjukkan bahwa komposisi spesies makrozoobentos yang ditemukan pada setiap stasiun tidak sama. Komposisi speseis makrozoobentos yang 
berbeda antar empat stasiun penga-matan diduga berkaitan erat dengan per-bedaarn tipe substrat dan kepadatan dan biomassa lamun sebagai habitat makro-zoobentos.

\section{KESIMPULAN}

Komposisi makrooobentos yang ditemukan pada empat stasiun di Teluk Doreri pada lokasi bervegetasi lamun terdiri atas 3 Kelas yaitu Gastropoda, Bivalvia dan Crustacea, sedangkan pada lokasi tidak bervegetasi terdiri atas 3 Kelas yaitu Gastropoda, Bivalvia dan Polychaeta. Kepadatan, keanekaragaman, dan keseragaman makrozoobentos di daerah bervegetasi di empat lokasi lebih tinggi dibandingkan pada daerah yang tidak bervegetasi. Nilai dominansi pada daerah berve-getasi dan daerah tidak bervegetasi menunjukkan nilai yang rendah yang mengin-dikasikan tidak ada spesies yang dominan. Kesamaan komunitas berdasarkan kesamaan spesies makrozoobentos di daerah bervegetasi dan tidak bervegetasi antara stasiun penelitian tidak sama, karena karakteristik habitat yang berbeda pada setiap stasiun pengamatan.

\section{DAFTAR PUSTAKA}

[APHA] American Public Health Association. 1989. Standard methods for the examination of water and waste water. $18^{\mathrm{ed}}$ Washington.

Bale AJ, Kenny AJ. 2005. Sediment analysis and seabed characterisation. dalam: Eleftheriou A, McIntyre A. Methods for the study of marine benthos, third eds. pp 43-86. Blackwell science Ltd.

Barnes RD. 1987. Invertebrate zoology, fifth eds. WB Sanders Company Philadel-phia, London,.

Bengen DG. 2002. Sinopsis ekosistem dan sumber daya alam pesisir dan laut serta prinsip pengelolaannya. Pusat Kajian Sumber daya Pesisir dan Lautan (PKSPL). Institut Pertanian Bogor. Bogor.

Bergey EA, Balling SF, Collins JN, Lamberti GA, Resh VH. 1992. Bio- nomic of invertebrates within extensive Potamo-geton pectinatus bed of a California masrh: Hydrobiologia 234: 15-24.

Butler GC. 1978. Principles of ecotoxicology scope 12. John Willey and Sons. New-York.

Brower JE, Zar JH, Von Ende.1990. General ecology, field and methods for general ecology. third eds. Iowa: America WM. C. Brown Companv Publisher Dubu-gue.

Connolly RM. 1997. Differences in composition of small, motile inver-tebrates assemblages from seagrass and unvegetated habitats in a Southern Australian estuary. Hydrobiologia 346: 137-148.

Day JH. 1962. A monographi on the polychaeta of Southern Africa (Errantia Part I dan Sedentaria Part II). Trustees of The British Museum (Natural History): Lon-don.

Dharma B. 1988. Siput dan kerang Indonesia I (Indonesian shells). Jakarta: PT Sara-na Graha.

Dharma B. 1992. Siput dan kerang Indonesia (Indonesian shells II). Wiesbaden: Verlag Christa Hemmen. Germany.

Dharma B. 2005. Recent and fosil Indonesian shells. Coonch-books. Hackenheim. Germany.

Hedgel P, Kriwoken L. 2001. Evidence for effects of Spartina anglica invasion on benthic macrofauna in Little Swanport estuary, Tasmania. Austral Ecology 25: 150-159.

Hynes HBN. 1978. The ecology of running waters. University of Toroto Press. To-roto. $555 \mathrm{p}$.

Kennish MJ. 1990. Ecology of estuaries; Volume II Biological apects. CRC Press, Inc. Florida.

Kopalit H. 2010. Analisis of seagrass beds as fish habitat function in Manokwari coastal waters, West Papua Province. (thesis). Graduate School of Bogor Agricultural University. Bogor.

Krebs CJ. 1989. Ecology methodology. New York: Harper and Rows Publisher. 
Lana P, Guis C. 1992. Macrofauna plant biomassa interactions in euryhaline salt marsh in Paranagua Bay (SE Brazil). Mar. Ecol. Prog. Ser. 266: 1-13.

Lanyon J. 1968. Guide to the identification of seagrasses in the Great Barier Reef Region. Publisher by GBRMPA. Queens-land.

Leatemia SPO. 2010. Distribusi spasial komunitas gastropoda dan asosiasinya dengan habitat lamun di Pesisir Manokwari Papua Barat (tesis). Pasca Sarjana, Institut Pertanian Bogor. Bogor.

Leatemia SPO, Pattiasina TF. 2008. Struktur komunitas makrozoobenthos dalam hubungannya dengan kondisi perairan pesisir Kota Manokwari. Jurnal Perikan dan Kelautan 4 (1): 31-44.

Levin LA, Talley TS, Hewitt J. 1998. Macrobenthos of Spartina foliosa (Pacific cordgrass) salt marshes in Southern California: Community struc-ture and comparison to a $\mathrm{Pa}-$ cific mudflats- and a Spartina alterniflora (Atlantic smooth cordgrass) marsh. Estuaries 21: 129-144.

McKenzie LJ, SJ. Campbell, CA. Roder. 2003. Seagrass-watch: Manual for mapping and monitoring seagrass resources by Community (Citizen) Volun-teers. Second edition. Department of Primery Industries. Queensland.

Mistri M, Fano EA, Rossi G, Caselli K, Rossi R. 2000. Variability in macrobenthos communities in the Valli di Camachio, Northern Italy. a Hypereuthropirized Logoonal Ecosystem. Estuar. Coast. Shelf Sci. 51: 599-611.

Mouillot D, Laune J, Tomasini JA, Aliaume C, Brehmer P, Dutrieux E, Chi TD. 2005a. Asssessment of coatal lagoon quality with taxonomy quality diversity indeces of fish, zoobenthos and macrophyta communities. 550:121-130.

Hydrobiologia

Mouillot D, Gaillard S, Aliaume C, Verlaque M, Belsher T, Troussellier M, Chi TD. 2005b. Ability of taxonomic diversity endeces to discriminate coastal lagoon environment based on macrophyte communities. Ecolo-gical indicators 5: 1-17.

Nybakken JW. 1992. Biologi laut: Suatu pendekatan ekologis. Terjemahan oleh Eidman M, Koesoebiono, Bengen DG, Hutomo M. Penerbit PT. Gramedia Pustaka. Jakarta.

Odum EP. 1993. Dasar-dasar ekologi. Penerjemah Samingan T. Gadjah Mada Press. Yogyakarta.

Orth RJ, Kenneth L. Heck Jr, Van Monfrans J. 1984. Faunal com-munities in seagrass bed; A review of the influence of plant structure and prey characteristic on predator-prey relationships. Estuaries 7: 339-350.

Pennak RW. 1978. Freswater inver-tebrates of the United States. Second eds. A Willey Inter Sclence Publication. Jhon Willey and Sons, Inc. New York, $462 \mathrm{p}$.

Pescod NB. 1973. Investigation of Relation Effluent and Stream for Tropical Countries.ALT. Bangkok.

Sukarno. 1988. Terumbu karang buatan sebagai sarana untuk meningkatkan produktivitas perikanan di Periaran Jepara. LON-LIPI. Jakarta.

Susetiono. 2004. Fauna padang lamun Tanjung Merah Selat Lembeh. Pusat Penelitian Oseanografi-LIPI. Bitung.

Van Houte-Howes KSS, Turner SJ, Pilditch CA. 2004. Spatial differences in macroinvertebrates communities in intertidal seagrass habitats and unvegetated sediment in three New Zealand Estuaries. Estuaries 6: 954-957.

Wolda H. 1981. Similarity indices, sample size and diversity. Smit-sonian Tropical Research Institut. Panama. 
